\title{
PANDUAN KEPALA SEKOLAH UNTUK MENGELOLA SEKOLAH PADA MASA PANDEMIC COVID-19
}

\author{
The Principal's Guide to Managing Schools During The Covid-19 Pandemic
}

\author{
Oleh: Djumiko*, Slamet Fauzan**, dan Muhammad Jailani*** \\ e-mail: slamet.fauzan.fe@um.ac.id
}

\begin{abstract}
ABSTRAK
Penelitian ini bertujuan untuk mengetahui upaya Kepala Sekolah SMK N 1 Songgom dalam mengoptimalkan peran aktif warga sekolah dalam mengembangkan layanan pendidikan di tengah pandemi covid-19. Penelitian ini menggunakan pendekatan kualitatif dan jenis penelitiannya adalah naratif study. Hasil penelitian menunjukkan bahwa upaya yang dilakukan secara intern oleh Kepala Sekolah antara lain optimalisasi layanan pembelajaran daring, optimalisasi layanan administrasi sekolah dan optimalisasi pemenuhan serta perawatan fasilitas sekolah. Sedangkan upaya yang dilakukan untuk ekstern atau warga masyarakat sekitar, yaitu menerjunkan tim untuk pembagian Hand Sanitizer buatan guru SMK Negeri 1 Songgom sekaligus memberikan edukasi terkait dengan protokol kesehatan pencegahan Covid-19. serta membuat vlog tentang pembelajaran daring dan himbauan pencegahan penyebaran covid-19 yang di unggah dan dibagikan melalui kanal Youtube Kepala Sekolah.
\end{abstract}

Kata Kunci : Kepala Sekolah, layanan Pendidikan, Pandemik, Covid-19.

\section{ABSTRACT}

This study aims to determine the efforts of the Principal of SMK N 1 Soggom in optimizing the active role of school residents in developing educational services in the midst of the Covid-19 pandemic. This research uses a qualitative approach and the type of research is a narrative study. The results showed that the efforts made internally by the principal included optimization of online learning services, optimizing school administration services and optimizing the fulfillment and maintenance of school facilities. Meanwhile, the efforts made for the external or local community members were deploying a team to distribute Hand Sanitizers made by teachers of SMK Negeri 1 Songgom as well as providing education related to the health protocol for preventing Covid-19. as well as creating vlogs about online learning and appeals to prevent the spread of Covid-19 which are uploaded and shared through the Principal's Youtube channel.

Keyword : Headmaster, Education Service, Pandemic, covid-19. 


\section{PENDAHULUAN}

Sejak diumumkan oleh pemerintah pada awal bulan maret, wabah Covid-19, semakin lama semakin banyak korban yang terkonfirmasi positif virus ini. Penyebaran virus corona yang berasal dari Wuhan Tiongkok ini sangat cepat, bahkan sampai dengan April 2020 tercatat ada 213 negara Maka sangatlah wajar jika WHO menetapkan wabah Covid-19 sebagai pandemi global. Peta sebaran Covid-19 di seluruh dunia yang diambil dari Johns Hopkins University (Baltimore, Amerika Serikat) per tanggal 23 April 2020 pukul 18.11 nampak sebagai yang menyatakan terkonfirmasi virus ini.

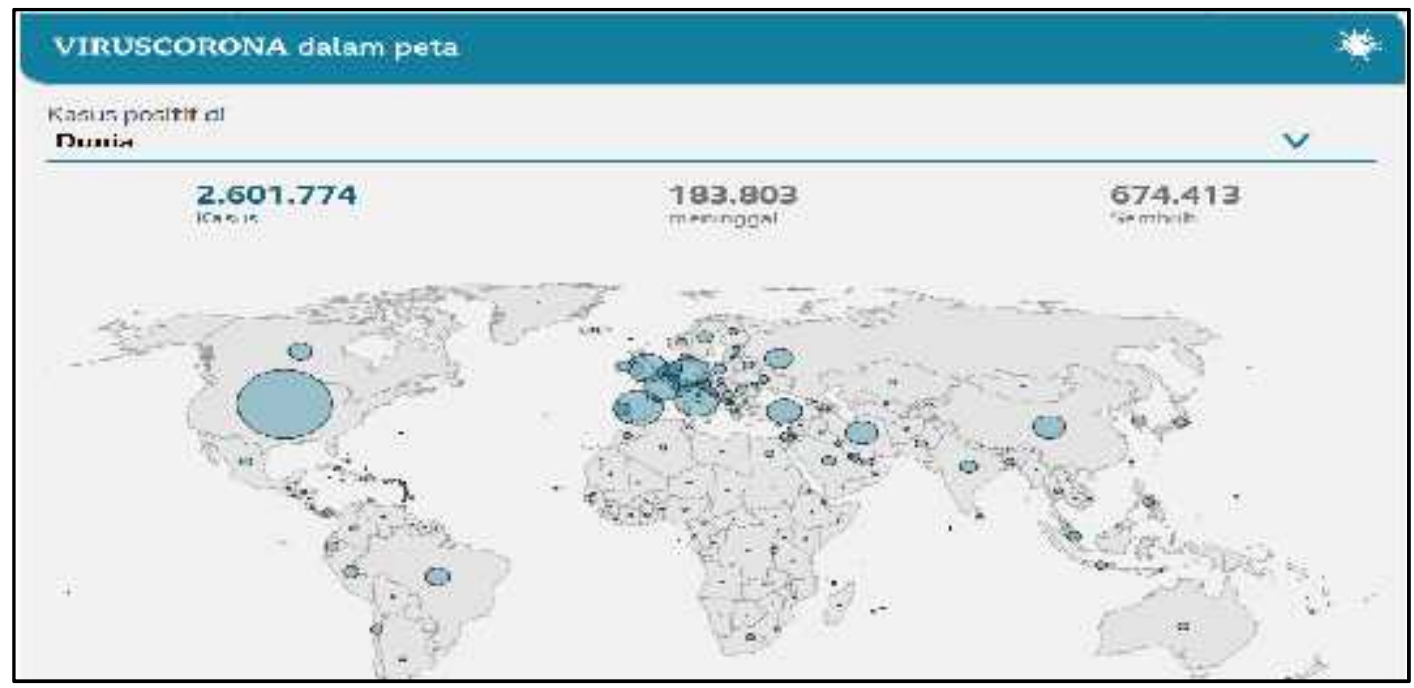

Gambar 1: peta sebaran Covid-19 diseluruh dunia (sumber : Johns Hopkins University, USA : 23 April 2020)

Peta diatas menunjukan betapa cepat penyebaran wabah Covid-19 diberbagai belahan dunia. Sampai dengan tanggal 23 April 2020 tercatat 2.601 .774 orang yang terkonfirmasi posiitf Covid-19 dengan 183.803 orang meninggal dunia dan 674.413 orang dinyatakan sembuh.

Di Indonesia sendiri wabah virus yang berasal dari Wuhan Tiongkok ini sejak pertama kali diumumkan oleh pemerintah juga grafiknya semakin naik. Berikut grafik jumlah kasus virus corona di Indonesia sampai dengan tanggal 23 April 2020 sudah terkonfirmasi positif corona sebanyak 7.775 orang, sedangkan dari jumlah tersebut 960 orang dinyatakan sembuh dan 647 orang meninggal dunia. Sedangkan sebaran wabah Covid-19 di pulau jawa masih yang tertinggi, setidaknya hal ini terlihat dari data yang dirilis oleh Kementerian Kesehatan RI per 23 April 2020 sebagai berikut : 


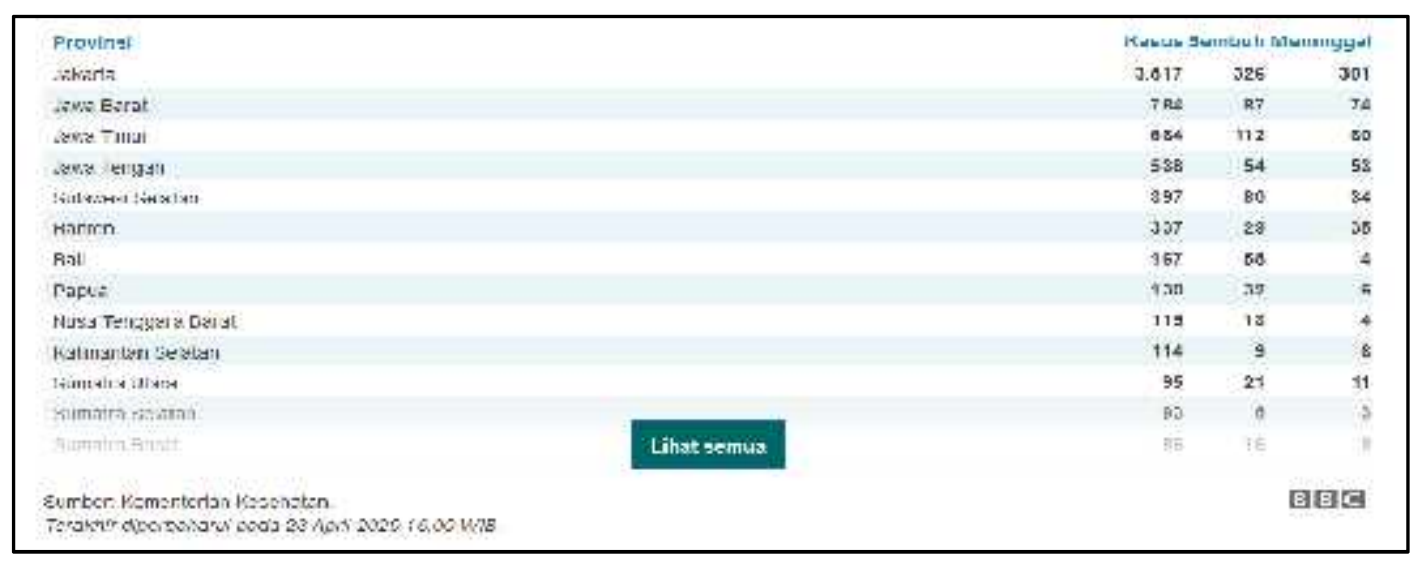

Gambar 2: Data penyebaran wabah Covid-19 di tiap Provinsi di Indonesia (sumber :

BBC Indonesia : 23 April 2020)

Data dan grafik yang tersaji diatas sudah cukup sebagai bukti betapa penyebaran wabah Covid-19 sangat mengawatirkan. Maka diperlukan langkah konkrit dari setiap elemen masyarakat untuk mencegah penularan wabah Covid19. Salah satu bentuk pencegahan terhadap penyebaran wabah Covid-19 adalah dengan melakukan social distancing atau fisical distancing, yaitu dengan menjaga jarak atau menghindari kontak langsung karena penularan Covid19 ini terjadi antar manusia melalui droplet atau cairan yang keluar melalui batuk atau bersin orang yang positif Covid-19. Untuk itu protokol kesehatan yang diterapkan oleh pemerintah melalui kementerian kesehatan RI adalah dengan menjada jarak untuk tidak melakukam kontak fisik minimal sejauh 1,5 meter sesuai standar WHO.

Sekolah sebagai tempat berkerumunnya individu dinilai rentan terhadap penyebaran wabah Covid-19, untuk itu sejak tanggal 24 Maret 2020 Menteri Pendidikan dan Kebudayaan RI mengeluarkan surat edaran nomor 4 tahun 2020 tentang pelaksanaan kebijakan pendidikan dalam masa darurat penyebaran coronavirus disease (Covid-19). Surat edaran tersebut memuat kebijakan tentang belajar di rumah bagi peserta didik, yaitu mengalihkan jadwal pembelajaran tatap muka menjadi jadwal pembelajaran daring/online. Implikasi dari kebijakan tersebut menuntut kepemimpinan kepala sekolah sebagai kepala pembelajaran untuk kreatif dalam memotivasi peserta didik dan guru, agar kebijakan pembelajaran daring/online dapat berjalan dengan baik.

Kepala Sekolah memiliki fungsi sebagai manajer, artinya Kepala Sekolah harus mampu mengelola sumberdaya yang ada disekolah agar di optimalkan dalam mengatasi permasalahan pembelajaran pada kondisi sesulit apapun. Karakteristik sekolah menengah kejuruan dengan mata pelajaran yang lebih menekankan unjuk kerja (ketrampilan) menjadi permasalahan khusus yang harus diatasi dalam pembelajaran daring. Mengingat pembelajaran daring jelas sulit untuk mengukur unjuk kerja dari peserta didik. Latar belakang peserta didik SMK yang rata-rata berasal dari keluarga menengah kebawah, menjadi permasalahan 


\begin{abstract}
berikutnya dalam pelaksanaan pembelajaran daring. Dimana pembelajaran daring/online menuntut peserta didik untuk memiiki perangkat telepon pintar (smartphone) yang dapat menunjang pembelajaran secara online. Latar belakang ekonomi orang tua peserta didik terkadang menjadi kendala dalam partisipasi peserta didik untuk mengikuti pembelajaran daring. Untuk pemenuhan kebutuhan hidup sehari-hari dimasa pandemi seperti sekarang ini jelas sangatlah sulit, apalagi harus dibebani dengan dukungan kuota internet dari orang tua peserta didik untuk mendukung keberhasilan pembelajaran daring putraputrinya.
\end{abstract}

Sekolah Menengah Kejuruan (SMK) Negeri 1 Songgom merupakan satuan pendidikan formal yang didirikan sejak tahun 2015. Saat ini SMK Negeri 1 Songgom memiliki 2 Kompetensi Keahlian yaitu Teknik dan Bisnis Sepeda Motor (TBSM) dan Teknik Komputer Jaringan (TKJ) dengan jumlah peserta didik sebanyak 358 orang yang terdaftar di Dapodik per April 2020. Jumlah tenaga pendidik (Guru) sebanyak 18 orang dengan tenaga kependidikan (staf TU) semuanya berstatus tenaga honorer Provinsi. Demografi lingkungan sekitar sekolah yang merupakan daerah agraris dengan pengahsilan orang tua peserta didik ratarata mengandalkan dari hasil pertanian, merupakan salah satu faktor yang ikut mempengaruhi pola pikir peserta didik terhadap kegiatan pembelajaran. Rata-rata kondisi perekonomian orang tua/wali peserta didik SMK Negeri 1 Songgom adalah berasal dari golongan menengah kebawah, maka saat terjadi pandemi seperti sekarang ini, dimana perekonomian global melemah, secara langsung juga berpengaruh terhadap kondisi ekonomi masyarakat termasuk orang tua peserta didik. Hal ini tentunya memengaruhi layanan pembelajaran selama masa pandemi Covid-19 yang telah direncanakan oleh pihak sekolah. Sesuai dengan kebijakan pemerintah, selama masa pandemi Covid-19, maka mewajibkan sekolah melaksanakan pembelajaran dalam jaringan (daring) dengan memanfaatkan media internet. Konsekuensinya adalah menuntut peserta didik menyediakan perangkat pendukung berupa smartphone dan fasilitas pendukung lainnya berupa kuota data internet. Tuntutan ini tentunya menjadi beban tambahan bagi orang tua/wali peserta didik.

Kondisi yang terurai tersebut diatas harus disikapi oleh seluruh warga sekolah terutama kepemimpinan Kepala Sekolah dalam mengoptimalkan sumberdaya yang ada sehingga layanan pendidikan ditengah pandemi Covid-19 tetap berlangsungg dengan baik. Disamping itu sekolah juga diharapkan dapat berkontribusi terhadap masyarakat sekitar lingkungan sekolah dalam mencegah penyebaran wabah Covid-19. Atas dasar hal tersebut maka penelitian ini sangat penting untuk dilakukan dalam mengoptimalkan layanan pembelajaran ditengah pandemi Covid-19.

\section{METODE PENELITIAN}

Penelitian ini merupakan penelitian dengan menggunakan pendekatan kualitatif. Moleong (2012:6) menjelaskan penelitian kualitatif merupakan penelitian yang bertujuan untuk memahami fenomena tentang apa yang dialami subjek penelitian seperti, perilaku, persepsi, motivasi, dll, yang dideskripsikan dalam bentuk kata - 
kata dan bahasa yang alamiah dan dengan menggunakan metode - metode ilmiah. Jenis penelitian yang digunakan dalam penelitian ini adalah jenis penelitian naratif study.

Pada penelitian ini, peneliti terjun langsung ke SMK N 1 Songgom Kabupaten Brebes untuk mencari informasi yang mendalam terkait pelaksanaan upaya Kepala Sekolah dalam mengoptimalkan peran aktif warga sekolah dalam pengembangan layanan pendidikan di tengah pandemic covid-19. Serta bagaimana kontribusi SMK Negeri 1 Songgom terhadap masyarakat di lingkungan sekitar sekolah dalam upaya pencegahan penyebaran wabah Covid-19. Salah satu peneliti adalah subjek dari penelitian ini yaitu Kepala Sekolah SMK tersebut. Peneliti melakukan observasi langsung dengan cara mengamati kegiatan pelayanan pendidikan, baik sifatnya kepada masyarakat sekolah, likungan, maupun stakeholder yang lain.

Penelitian ini menggunakan data primer maupun data sekunder. Adapun data primer merupakan data yang diperoleh secara langsung oleh peneliti, tanpa melalui perantara, seperti catatan hasil wawancara dan hasil pengamatan atau observasi langsung, data primer dapat diperoleh melalui kegiatan wawancara, dan observasi atau pengamatan langsung ke lapangan (Sugiyono, 2016:225). Sedangkan data sekunder merupakan data yang diperoleh melalui perantara, misalnya seperti penelitian terdahulu, laporan keuangan, buku, serta dokumen lainnya.

Teknik analisis data yang digunakan dalam penelitian ini yaitu :

1. Noema
Dalam tahap awal ini peneliti mengidentifikasi noema atau apa yang biasa disebut dengan analisis tekstural yang berarti permukaan atau awal (Kamayanti, 2016:154).

\section{Epoche (Braketing)}

Dari hasil analisis noema, peneliti melakukan bracketing atau memberi tanda kurung (Kamayanti, 2016:154). Bracketing atau tanda kurung ini digunakan ketika informan memberikan asumsi-asumsi pribadinya (Sobur, 2013:428).

3. Noesis

Noesis adalah makna yang lebih dalam dan menjadi kesadaran murni yang muncul akibat adanya pengalaman yang di dapatkan masing-masing individu, karena waktu (Allraum) dan tempat (Welzeit) tertentu (Kamayanti, 2016:154).

\section{Intentional Analysis}

Intentional Analysis adalah pemahaman mengenai korelasi antara noema dan noesis yang digunakan peneliti untuk mengambil sebuah pemahaman lanjutan tentang bagaimana noesis dapat membentuk noema (Kamayanti, 2016:200).

\section{Eidetic Reduction}

Pada tahap ini, peneliti menggabungkan seluruh proses pemaknaan yang di peroleh dari hasil wawancara setiap informan yang memiliki pemaknaan yang berbeda-beda mengenai pernyataan kegiatan Kepala Sekolah dalam mengoptimalkan peran aktif warga sekolah dalam pengembangan layanan pendidikan di tengah pandemic covid-19 (Kamayanti, 2016:154)

\section{HASIL PENELITIAN}

1. Upaya Kepala SMK Negeri 1 Songgom dalam mengoptimalkan layanan pendidikan di tengah 
pandemi Covid-19

a. Layanan Pembelajaran Daring / Online

Sejak keluarnya edaran Menteri Pendidikan dan Kebudayaan Nomor 4 Tahun 2020 tentang pelaksanaan kebijakan pendidikan dalam masa darurat penyebaran coronavirus disease (Covid-19), berimplikasi pada perubahan layanan pembelajaran di sekolah. Terhitung sejak tanggal 16 Maret 2020 SMK Negeri 1 Songgom menerapkan kebijakan pembelajaran daring/online bagi guru dan peserta didik. Hal ini sejalan dengan surat edaran Kepala Dinas Pendidikan dan Kebudayaan Provinsi Jawa Tengah Nomor 443.2/08991 tanggal 15 Maret 2020 tentang Pengaturan pelaksanaan Ujian Nasional/Ujian Sekolah dan kegiatan belajar mengajar pada SMA, SMK dan SLB Provinsi Jawa Tengah Tahun Pelajaran 2019/2020. Dalam edaran tersebut tidak hanya berisi penundaan Ujian Nasional tetapi juga berisi anjuran untuk melaksanakan pembelajaran secara online bagi peserta didik dalam masa pendemi Covid-19.

SMK Negeri 1 Songgom menyikapi edaran dari Kepala Dinas Pendidikan dan Kebudayaan Provinsi Jawa Tengah, dengan membentuk Satuan Tugas (Satgas) Optimalisasi Pelayanan Pendidikan dimasa Pandemi Covid-19. Satgas diketuai oleh Bapak Yopi Apriliansyah Hidayat, S.Pd selaku WKS Kesiswaan dengan bertanggungjawab langsung kepada
Kepala Sekolah. Hal yang pertama dilakukan adalah pada hari pertama pemberlakuan kebijakan belajar dirumah lewat daring, Kepala Sekolah selaku Kepala SMK Negeri 1 Songgom mengajak seluurh guru untuk berkumpul di laboratorium Komputer, untuk melaksanakan bimbingan teknis terkait pemanfaatan Google Classroom dan Google Form dalam pembelajaran daring/online. Kepala Sekolah menunjuk Bapak Andri Tri Martiono, S.Kom selaku WKS Kurikulum sekaligus guru produktif TKJ untun menjadi narasumber dalam kegiatan bimtek tersebut. Dalam Bimtek tersebut dibahas mengenai cara membuat kelas maya, menambahkan peserta didik ke kelas, mengelola pertemuan pembelajaran, melakukan evaluasi penilaian, sharing materi pada peserta didik, dan pengelolaan presensi daring lewat google form. Berikut dokumentasi kegiatan bimtek pemanfaat google classroom dan google form dalam menunjang pembelajaran daring yang dilakukan oleh SMK Negeri 1 Songgom

Setelah kegiatan Bimtek selesai, guru langsung praktik membuat kelas daring sesuai dengan mata pelajaran yang diampu, dan memasukan Kepala Sekolah dalam kelas masing-masing untuk tujuan pemantauan pelaksanaan pembelajaran daring. Data yang dihimpun oleh peneliti terkait partisipasi peserta didik yang bergabung dalam kelas pembelajaran daring pada hari pertama 
pemberlakuan kegiatan pembelajaran daring sebanyak 64\%. Permasalahan yang muncul keterlibatan peserta didik yang belum mencapai $100 \%$ karena pola ini merupakan pertama di terapkan, sehingga beberapa laporan dari wali kelas adalah terkait dengan sumberdaya yang dimiliki peserta didik untuk mengikuti pembelajaran daring, seperti ketersediaan smartphone dengan kapasitas memori mencukupi dan ketersediaan kuota data internet.

Kebijakan yang diambil Kepala SMK Negeri 1 Songgom terkait kegiatan pembelajaran daring/online adalah dengan memindahkan jadwal KBM reguler tatap muka menjadi jadwal KBM daring/online. Sehingga kegiatan pembelajaran juga dimulai pukul 07.00 dan berakhir pukul 15.30 untuk hari Senin - Kamis, sedangkan pada hari Jum'at dimulai pukul 07.00 dan diakhiri pukul 14.30. Dengan masuknya Kepala Sekolah ke dalam kelas daring, maka Kepala Sekolah selaku Kepala Sekolah dapat memantau keterlaksanaan pembelajaran daring sekaligus memantau partisipasi peserta didik dalam kegiatan tersebut.

Optimalisasi terhadap layanan pembelajaran daring yang dilakukan Kepala Sekolah adalah dengan menyediakan media pemantauan KBM daring berupa jurnal aktivitas KBM daring yang ditautkan dengan memanfaatkan google form. Jurnal aktivitas KBM daring wajib diisi oleh guru setelah melaksanakan pembelajaran dengan sub menu isian antara lain : nama guru, mata pelajaran, kelas, waktu mulai KBM, waktu mengakhiri KBM, jumlah peserta didik yang seharusnya hadir, jumlah peserta didik yang hadir, jumlah peserta didik yang tidak hadir, nama dan keterangan peserta didik yang tidak hadir, materi/KD yang di bahas dalam pembelajaran daring, serta screnshoot aktivitas pembelajaran..

Dua pekan pertama kegiatan pembelajaran daring seluruh guru melaksanakan dengan baik sesuai jadwal KBM reguler. Disisi lain partisipasi peserta didik pada setiap kelas belum mencapai $100 \%$. Kenyataan tersebut menuntut Kepala Sekolah untuk mencari solusi agar partisipasi peserta didik dalam pembelajaran daring minimal mendekati $100 \%$. Langkah pertama yang dilakukan Kepala Sekolah adalah melakukan koordinasi dengan Guru terutama wali kelas untuk mencari akar masalah ketidakikutan beberapa peserta didik dalam pembelajaran daring. Koordinasi dilakukan melalui daring/online dengan memanfaatkan aplikasi video converence Teamlink.

Hasil evaluasi pembelajaran daring yang dilakukan Kepala Sekolah dengan guru melalui Vicon menemukan fakta bahwa ketidakikutan beberapa peserta didik dalam pembelejaran daring pada 2 pekan pertama karena peserta didik tidak memiliki kuota internet. Bahkan ada 4 orang peserta didik yang tidak memiliki perangkat smartphone dari kelas XI TBSM 1 
dan kelas X TKJ 2. Hal ini terungkap dari laporan masing-masing wali kelas kepada Kepala Sekolah saat vicon berlangsung. Untuk mengatasi permasalah pertama yaitu kesulitan dalam pemenuhan kuota internet, maka Kepala Sekolah melakukan koordinasi dengan bendahara BOP untuk mengalihkan anggaran pelaksanaan UNBK yang dibatalkan oleh pemerintah, menjadi anggaran pemenuhan kuota data internet.

Langkah berikutnya setelah mengetahui pendanaan untuk pemberian subsidi kuota internet mencukupi maka kepala sekolah membuat Prosedur Operasi Standar (POS) tentang pemberian subsidi kuota data internet yang memuat antara lain mekanisme pemberian subsidi. POS tersebut tertuang dalam surat keputusan (SK) Kepala SMK Negeri 1 Songgom nomor 421.5/102.a/III/2020 tanggal 30 Maret 2020. Dengan POS tersebut makan pemberian subsidi kuota data bagi peserta didik akan lebih terarah, adapun POS yang dimaksud Kepala Sekolah lampirkan dalam karya tulis ini.

Operasionalisasi dari implementasi POS pemberian subsidi kuota data internet bagi peserta didik diwujudkan dalam bentuk penerbitan surat keputusan (SK) Kepala SMK Negeri 1 Songgom nomor 421.5/130/III/2020 tanggal 30 Maret 2020 tentang pemberian subsidi kuota data internet bagi peserta didik. Dalam SK tersebut memuat daftar nama peserta didik yang layak mendapatkan subsidi kuota sesuai dengan ketentuan yang tertera dalam POS pemberian subsidi. Peserta didik yang diberikan SK pemberian subsidi setelah melalui seleksi yang dilakukan oleh satgas yang dibentuk oleh kepala sekolah, antara lain berasal dari keluarga kurang mampu, yang dibuktikan dengan kepemilikan Kartu Indonesia Pintar (KIP). Pemberian subsidi kuota data internet bagi peserta didik, diberikan untuk paket kuota selama 15 hari, setelah 15 hari nantinya diisi kuota lagi. Hal ini dimaksudkan agar penggunaan kuota data internet dapat terkontrol, hanya benar-benar untuk menunjang kegiatan pembelajaran daring.

Melengkapi 2 instrumen tersebut diatas, Kepala Sekolah juga membuat instrumen evaluasi pembelajaran daring yang harus diisi oleh peserta didik dan guru yang ditautkan melalui google form. Instrumen evaluasi tersebut berisi pertanyaan seputar efektifitas pelaksanaan pembelajaran daring yang sudah dilaksanakan selama 2 pekan, kendala yang dihadapi serta usulan dari guru dan peserta didik untuk pembelajaran daring pada sesi berikutnya. Ada 20 pertanyaan dalam instrumen evaluasi pembelajaran daring sebagai cara Kepala Sekolah untuk mengetahui sejauhmana efektifitas pelaksanaan pembelajaran daring yang telah dilakukan. Berikut daftar pertanyaan yang diajukan oleh Kepala Sekolah melalui tautan google form :

1) Apakah guru memulai KBM 
daring sesuai dg jadwal KBM reguler?

2) Apakah guru memulai KBM daring pada jam pertama dan mengakhiri KBM daring pada Jam terakhir dengan berdoa?

3) Apakah guru selalu melakukan cek kehadiran peserta didik (presensi) sebelum memulai pembelajaran

4) Apakah guru memberikan materi pelajaran secara live melalui video conference?

5) Sebutkan mapel apa saja yang menggunakan pembelajaran live atau video conference

6) Apakah guru memberikan materi pelajaran berupa bacaan melalui link yang dapat di download oleh perserta didik

7) Sebutkan mapel apasaja yang memberikan bahan bacaan melalui link yang dapat di download oleh perserta didik

8) Apakah anda selalu mengikuti pembelajaran daring sesuai dengan jadwal KBM reguler?

9) Apakah anda hadir tepat waktu dalam pembelajaran daring sesuai dengan jadwal reguler

10) Apakah guru mapel, disamping menyampaikan materi sesuai mata pelajaran, juga menyampaikan nilai-nilai sikap/karakter kepada peserta didik? Contoh : mengingatkan untuk sholat, ketika waktu sholat telah tiba, mengingatkan peserta didik untuk disiplin waktu, menegur peserta didik yang terlambat bergabung dalam pembelajaran daring, saling menghormati pendapat dan jawaban teman, dan lainlain

11) Sebutkan mata pelajaran yang memberikan muatan karakter/sikap, disamping muatan mata pelajaran, saat berlangsung pembelajaran daring

12) Apakah ada mata pelajaran yang hanya memberikan tugas saja disetiap pembelajaran daring

13) Sebutkan mata pelajaran yang hanya memberikan tugas saat jadwal pembelajaran daring berlangsung

14) Jenis tugas apa yang menurut anda terlalu berat untuk diselesaikan, uraikan alasan anda

15) Saluran internet apa yang anda gunakan untuk menunjang pembelajaran daring

a. Wifi Gratis yang disediakan di lingkungan tempat tinggal

b. Indihome dari telkom

c. Paket Data internet dari provider seluler (telkomsel, indosat, Tri, XL, Smartfrend, provider lain)

16) Jika pada point 15 anda memilih C, Berapa kuota paket data yang anda butuhkan untuk menunjang pembelajaran daring dalam 15 hari

17) Jika pada point 15 anda memilih C, Apakah didaerah anda sinyal 4G LTE cukup baik? 
18) Apakah orang tua/wali anda ikut mendukung terhadap kegiatan pembelajaran daring ?

19) Sebutkan bentuk dukungan dari orang tua / wali anda terhadap kegiatan pembelajaran daring yang di lakukan sekolah

20) Apa saja saran dan masukan anda terhadap proses pelaksanaan pembelajaran daring yang selama ini sudah dilaksanakan?

Hasil instrumen evaluasi tersebut digunakan oleh Kepala Sekolah untuk melakukan evaluasi menyeluruh terhadap pelaksanaan pembelajaran daring. Hasil isian instrumen tersebut terlampir dalam karya tulis ini.

Terkait dengan permasalahan kedua, yaitu terdapat 4 peserta didik yang tidak memiliki perangkat smartphone, maka Kepala Sekolah meminta walikelas untuk melakukan homevisit sekaligus membawa materi dalam bentuk hardcopy dari semua guru mapel, untuk dipelajari oleh peserta didik yang tidak memiliki smartphone tersebut. Hasil home visit walikelas sangat menyisakan kepiluan di hati peneliti, mengingat kondisi ekonomi orang tua peserta didik atas nama Riyanto, yang memang sangat memprihatinkan. Untuk meringankan beban pembelajaran peserta didik yang tidak memiliki smartphone, maka walikelas secara rutin mengirimkan materi hardcopy dengan menerapkan protokol kesehatan dari pemerintah. Hak peserta didik untuk mendapatkan materi pelajaran tetap terlayani di tengah keterbatasan yang ada. Hasil kunjungan walikelas ke rumah orang tua peserta didik membawa dampat positif terhadap semangat peserta didik untuk terus belajar, yang sebelumnya minder akibat tidak bisa mengikuti pembelajaran daring/online.

\section{b. Layanan Administrasi Sekolah Tanggal 17 Maret 2020 Kepala} Dinas Pendidikan dan Kebudayaan Provinsi Jawa Tengah, mengeluarkan Nota Dinas Nomor : 0522/KADIN/III/2020, tentang pengaturan pelaksanaan masuk kerja bagi pendidik dan tenaga kependidikan SMA, SMK dan SLB di Jawa Tengah. Implikasi dari nota dinas tersebut disikapi oleh Kepala Sekolah dengan menyusun jadwal piket di sekolah bagi pendidik dan tenaga kependidikan. Piket yang dilaksanakan oleh pendidik di sekolah dilakukan dengan mengerjakan tugas-tugas pokok dan tugas tambahan guru terutama yang tidak bisa diselesaikan di rumah. Sedangkan pendidik yang tidak piket di sekolah tetap melaksanakan tugas utama guru dan tugas tambahannya dari rumah masing-masing melalui online. Pemantauan tetap dilakukan oleh kepala sekolah melalui media jurnal aktivitas KBM yang wajib diisi oleh semua guru.

Layanan tenaga kependidikan (tenaga administrasi) juga mengikuti kebijakan dari nota dinas tersebut. Kepala Sekolah juga menyusun jadwal piket di sekolah bagi tenaga kependidikan. Pekerjaan yang dilakukan di sekolah adalah pekerjaan-pekerjaan yang tidak mungkin diselesaikan di rumah. Sedangkan tugas-tugas adminstrasi yang bisa dilakukan dirumah maka tenaga kependidikan bisa melakukannya dengan pola work from home (WFH). Pekerjaan tenaga kependidikan yang dapat diselesaikan di rumah misalnya input data 
dapodik, input aset sekolah, pembuatan surat keluar, dan mengisian buku induk siswa. Sedangkan beberapa pekerjaan tenaga kependidikan yang tidak bisa diselesaikan di rumah, maka tenaga kependidikan wajib hadir, seperti petugas kebersihan sekolah, petugas keamanan sekolah dan petugas pengarsipan surat masuk. Media pemantaun kinerja tenaga kependidikan juga disiapkan oleh Kepala Sekolah berupa jurnal aktivitas tenaga kependidikan, yang wajib diisi oleh semua tenaga kependidikan baik yang piket di sekolah maupun yang melaksanakan bekerja di rumah. Jurnal tersebut ditautkan ke google form, sehingga memungkinkan diisi oleh semua tenaga kependidikan secara online.

Pengukuran kinerja tenaga kependidikan juga dilakukan oleh Kepala Sekolah dengan menetapkan target harian yang harus diselesaikan oleh masingmasing tenaga kependidikan sesuai dengan pembagian bidang tugas. Pengukuran kinerja tersebut diperoleh dari laporan masing-masing tenaga kependidikan yang dikirim melalui tautan google form yang disiapkan sebelumnya oleh Kepala Sekolah. Muara dari pengukuran kinerja tersebut adalah optimalisasi layanan pendidikan yang berkualitas di SMK Negeri 1 Songgom kepada masyarakat terutama peserta didik dan seluruh warga sekolah.

Kinerja pendidik dan tenaga kependidikan di SMK Negeri 1 Songgom terus dipantau oleh Kepala Sekolah, hal ini untuk memastikan bahwa layanan pendidikan di SMK Negeri 1 Songgom berjalan optimal. Teriring adanya kebijakan meniadakan presensi kehadiran bagi pendidik dan tenaga kependidikan yang melaksanakan piket di sekolah, disikapi oleh Kepala Sekolah dengan menggunakan presensi kehadiran memanfaatkan aplikasi timestamp camera. Dimana aplikasi ini merupakan aplikasi pengambilan gambar selfi, dengan memberikan keterangan pada foto mengenai titik koordinat dimana gambar diambil, tanggal berapa gambar diambil, pukul berapa gambar diambil dan lokasi pengambilan gambar. Aplikasi ini dibantu dengan satelit dengan memanfaatkan lokasi GPS yang ada pada smartphone pengguna. Dengan aplikasi ini, maka pendidik dan tenaga kependidikan yang melaksanakan piket di sekolah dapat terpantau. Begitu mereka hadir di sekolah, maka langsung mengambil posisi foto selfi dan foto tersebut dikirim ke group WA sekolah, sehingga dapat diketahui apakah pendidik dan tenaga kependidikan yang piket disekolah terlambat datang atau tidak. Ketika pulang piket, mereka wajib untuk mengambil foto selfi dengan aplikasi timestmap camera, dan mengunggahnya di group WA sekolah. Dengan demikian waktu kehadiran dan waktu pulang pendidik dan tenaga kependidikan tetap terpantau oleh Kepala Sekolah.

\section{c. Layanan Pemenuhan dan Perbaikan Fasilitas Sekolah}

Kebijakan pemerintah tentang belajar di rumah bagi peserta didik membuat aktivitas belajar mengajar di sekolah terhenti. Kondisi ini dimanfaatkan oleh Kepala Sekolah untuk melakukan pembenahan-pembenahan terhadap optimalisasi fasilitas sekolah. Pembenahan pertama yang dilakukan adalah dengan menata ulang ruang guru, yang selama ini menggunakan ruang perpustakaan. 
Penataan ini dimaksudkan agar spot area untuk perpustakaan menjadi lebih luas, dan guru nyaman dalam melaksanakan tugas. Beberapa peralatan dan bahan penunjang KBM yang selama ini menumpuk di ruang guru, dipindahkan ke almari ruang tata usaha, sehingga spot area untuk perpustakaan dan meja kursi guru lebih tertata dengan baik.

Penataan berikutnya adalah melakukan rehabilitasi ruang penunjang berupa toilet. Selama ini toilet laki-laki dan perempuan berjajar dengan akses masuk hanya 1 lorong. Penataan yang dilakukan Kepala Sekolah, dengan membangun tembok skat lorong untuk menuju ke toliet laki-laki dan toilet perempuan, sehingga saat mereka hendak memanfaatkan toilet, tidak bertemu antara peserta didik laki-laki dan perempuan dalam satu lorong yang sama. Disamping itu pada toilet laki-laki diberi tambahan urinoir agar pemanfaatan ruang toilet lebih optimal. Sedangkan pada toilet perempuan ada penambahan kamar mandi dan kamar ganti, yang dapat dimanfaatkan untuk ganti baju saat jam pembelajaran PJOK. Selama ini toilet yang ada hanya 2 kamar mandi dan dimanfaatkan oleh seluruh peserta didik sebanyak 358 orang. Melihat kondisi tersebut, maka prioritas utama yang Kepala Sekolah lakukan adalah dengan optimalisasi toilet yang merupakan salah satu ruang penunjang dalam pelaksanakan pembelajaran.

Pemenuhan dan penataan fasilitas sekolah berikutnya yang dilakukan Kepala Sekolah adalah melakukan pembenahan saluran air. Saat musim penghujan, lapangan dan halaman depan sekolah tidak dapat digunakan karena genangan air yang tidak bisa mengalir. Melihat kondisi tersebut, maka Kepala Sekolah berinisiatif untuk membuat saluran air dan membuat sodetan dengan memasang paralon agar genangan air dihalaman sekolah dan lapangan bisa cepat kering, dan air bisa mengalir ke saluran air.

Pembenahan berikutnya terhadap fasilitas sekolah yang dilakukan Kepala Sekolah selama masa pandemi Covid-19 adalah perbaikan mebeler atau meja dan kursi ruang kelas yang mengalami kerusakan. Baik rusak sedang, ringan maupun berat. Selama ini banyak kursi dan meja yang tidak dapat dimanfaatkan untuk kegiatan pembelajran dengan baik, karena kondisi yang memang sudah rusak dan tidak layak. Maka disaat peserta didik melakukan aktifitas belajar dirumah, penulia melakukan perbaikan menyeluruh terhadap meja dan kursi di ruang kelas. Perbaikan dilakukan oleh tenaga kependidikan sekolah yang mempunyai keahlian di bidang pertukangan kayu.

2. Kontribusi SMK Negeri 1 Songgom terhadap masyarakat di lingkungan sekitar sekolah dalam upaya pencegahan penyebaran wabah Covid-19

Upaya pencegahan penyebaran wabah Covid-19 juga dilakukan oleh Kepala Sekolah melalui kontribusi nyata bagi warga masyarakat sekitar sekolah, dengan membuat hand sanitizer oleh guru kimia SMK Negeri 1 Songgom. Hand sanitizer tersebut nantinya dibagikan kepada warga masyarakat di sekitar sekolah yang sering melakukan aktivitas di luar rumah, seperti pedagang di pasar dan lain-lain. Pembuatan hand sanitizer tersebut dimaksudkan sebagai media praktik dengan tetap berpedoman pada 
ketentuan komposisi hand sanitizer yang dikeluarkan oleh BPOM Kementerian Kesehatan RI. Pembagian hand sanitizer buatan SMK Negeri 1 Songgom dilakukan oleh guru yang melaksanakan piket pada hari tersebut. Saat pembagian juga dilakukan kampanye terhadap pencegahan wabah Covid-19 oleh guru kepada warga masyarakat sekitar. Kampanye tersebut antara lain seperti menggunakan masker saat keluar rumah, tidak keluar rumah jika tidak ada kepentingan, sering mencuci tangan memakai sabun, atau menggunakan hand sanitizer jika tidak ditemui air untuk cuci tangan, dan tetap menjaga jarak serta menghindari kerumunan.

Kontribusi berikutnya yang dilakukan Kepala Sekolah terhadap pencegahan penyebaran wabah Covid-19 adalah dengan membuat Vlog berisi himbauan tentang upaya sekolah dalam mengoptimalkan layanan pendidikan dan pencegahan penyebaran wabah Covid-19. Himbauan tersebut direkam langsung oleh Kepala Sekolah dan dibagikan melalui kanal Youtube milik Kepala Sekolah pada laman

https://www.youtube.com/watch?v=BLyI

N7nXyak

\section{SIMPULAN DAN SARAN}

Pemberlakuan kebijakan belajar dan bekerja dari rumah terkait dengan pencegahan penyebaran wabah Covid-19 dari pemerintah, disikapi oleh Kepala SMK Negeri 1 Songgom dengan menerapkan berbagai kebijakan sekolah yang muaranya pada optimalisasi layanan pendidikan. Upaya yang dilakukan secara intern dalam optimalisasi layanan pendidikan di SMK Negeri 1 Songgom yang dilakukan Kepala Sekolah antara lain optimalisasi layanan pembelajaran daring, optimalisasi layanan administrasi sekolah dan optimalisasi pemenuhan serta perawatan fasilitas sekolah.

Terkait dengan upaya pencegahan penyebaran wabah Covid-19 untuk pihak ekstern atau warga masyarakat sekitar, Kepala SMK Negeri 1 Songgom telah berkontribusi dengan menerjunkan tim untuk pembagian Hand Sanitizer buatan guru SMK Negeri 1 Songgom, kepada warga masyarakat sekitar, sekaligus memberikan edukasi terkait dengan protokol kesehatan pencegahan Covid-19. Kepala Sekolah juga membuat vlog tentang pembelajaran daring dan himbauan pencegahan penyebaran covid-19 yang di unggah dan dibagikan melalui kanal Youtube Kepala Sekolah.

\section{DAFTAR PUSTAKA}

BBC Indonesia. 2020. Virus Corona: Peta dan Infografis Terkait Pasien Terinfeksi, Meninggal dan Sembuh Di Indonesia dan Dunia. https://www.bbc.com/indonesia/indo nesia-51850113. Diakses tanggal 23 April 2020

Creswell. J. W. 2012. Research Design: Qualitative, Quantitative, and Mixed Methods Approaches. Yogyakarta: Pustaka Pelajar.

Direktur Kesehatan Lingkungan. 2020. Panduan Pencegahan Penularan Covid-19 di Tempat Fasilitas Umum. Jakarta. Dirjen Kesmas Kemnkes RI

Ikhsan, Arfan. 2009. Akuntansi Manajemen Lingkungan.

Yogyakarta: Graha Ilmu.

Kamayanti, A. 2016. Metodologi Penelitian Kualitatif Akuntansi: 
Pengantar Religiositas Keilmuan. Jakarta Selatan: Yayasan Rumah Paneleh

Keputusan Presiden RI Nomor 11. 2020. Penetapan Kedaruratan Kesehatan Masyarakat Covid-19. Jakarta. Presiden Republik Indonesia

Kusumaningtias. 2013. Green Accounting Mengapa dan Bagaimana. Proceeding Seminar Nasional for Papers Sancall .

Kuswarno, Engkus. 2009. Metodologi Penelitian Fenomenologi: Konsepsi, Pedoman dan Contoh Penelitian. Bandung : Widia Padjajaran

Moleong, Lexy. J. 2012. Metodologi Penelitian Kualitatif. Bandung: Remaja Rosda Karya.

Mulyadi \& Rivai. 2009. Manjemen Sumber Daya Manusia. Jakarta: Salemba Empat.

Permadi, Ade Salahudin \& Muchlis Saini. 2017. Upaya Meningkatkan Hasil Belajar IPA melalui Penerapan Media Pembelajaran Berbasis Multimedia Peserta Didik. Bitnet: Jurnal Pendidikan Teknologi Informasi, 2(2):20-26.

Putra, Chandra Anugrah. 2017. Pemanfaatan Teknologi Gadget Sebagai Media Pembelajaran. Bitnet : Jurnal Pendidikan Teknologi Informasi, 2(2):1-10.

Setyawan, Dedy \& Muhammad Fitriadi. Penggunaan Media Tiga Dimensi dalam Meningkatkan Hasil Belajar Matematika Peserta Didik. Bitnet: Jurnal Pendidikan Teknologi Informasi, 2(1):1-7.

Sobur, A. 2013. Filsafat Komunikasi Tradisi Dan Metode Fenomenologi. Bandung: PT Remaja Rosdakarya.
Sugiyono. 2016. Memahami Penelitian Kualitatif. Bandung: Alfabet.

Surat Edaran Meteri Pendidikan dan Kebudayaan RI Nomor 4. 2020. Pelaksanaan Kebijakan Pendidikan dalam Masa Darurat Penyebaran Covid-19. Jakarta. Menteri Pendidikan dan Kebudayaan. 